Article

\title{
Perceptions of Future Teachers of Audiovisual Education and Communication. Challenges in Training for a Sustainable Education
}

\author{
Rosa Pilar Esteve-Faubel (ㄹ, Alba Oller-Benitez (1) and María Pilar Aparicio-Flores *(D) \\ Department of General Didactic and Specific Didactics, Faculty of Education, University of Alicante, \\ 03690 Alicante, Spain; rosapilar.esteve@ua.es (R.P.E.-F.); alba.oller@ua.es (A.O.-B.) \\ * Correspondence: pilar.aparicio@ua.es; Tel.: +34-965-903-723
}

Received: 13 November 2020; Accepted: 7 December 2020; Published: 9 December 2020

check for updates

\begin{abstract}
The education of future teachers is going through a crisis related to audiovisual education. Following what is known as the 2015-2030 Agenda, the world of education is being confronted with a new learning model that must respond to the proposals of the Sustainable Development Goals-SDGs. In this article, we want to emphasize the need for training future teachers to meet the new needs of media education, taking into account the increasing importance of sustainable development of children in relation to audiovisual media to maintain their welfare, skills and future prospects. For this reason, the objective of the study is to collect the perceptions of 278 future schoolteachers about the significance of audiovisual education and their own training on the subject, the socio-educational objectives of audiovisual tools, their positioning regarding audiovisual methodology and the concept of communication. Two ad-hoc questionnaires with an ex-post-facto design were used. The findings showed that a reduced percentage of students felt they had received full audiovisual training. Nevertheless, over half of the future schoolteachers considered their work in the classroom to be important for social and educational ends, both from a theoretical and a practical viewpoint. We believe it is necessary to provide audiovisual education to future schoolteachers based on students' interests and needs.
\end{abstract}

Keywords: audiovisual education; SDGs; training needs; socio-educational objectives; methodological approaches

\section{Introduction}

Education at all teaching levels is having to face society's growing needs regarding new modes of communication [1,2]. We must thus reflect on how identities are formed in the sphere of new social media connections, and understand the need for development as attending to both children's needs of well-being and to the collective sustainable well-being in a globalized world [3].

In this context, the United Nations General Assembly [4] approved the 2030 Agenda on the Sustainable Development Goals_SDGs_-aimed at improving all people' lives, leaving no one behind. Among the goals set to address the challenges raised in that agenda, particularly in number 4 , we want to point out the need to: (a) support quality, inclusive and equitable education for all; (b) ensure free and compulsory education (primary and secondary) for all children and youth, with an effective teaching-learning process; (c) increase the percentage of youth and adults who are professionally competent to access decent work and to promote and engage in entrepreneurship; (d) ensure that all students achieve the theoretical and practical skills essential for the promotion of sustainable development and lifestyle, as well as to advocate for human rights, gender equality and cultural diversity and contribute to peace and non-violence [4]. 
In this context, taking into account the current demands of society, the countries of the European Union, including Spain, need a quality education based, for example, and among other things, on technological training, and even more so if we take into account the current needs for educational intervention due to the COVID-19 pandemic. Recent trends consider media education as a tool for sustainability to insert young people into the Information Society or Knowledge Societies, as framed by UNESCO (United Nations Educational, Scientific and Cultural Organization) and civil society actors [5].

This initial approach establishes the need for identifying the perceptions of the future teachers towards their technological skills and their training in this context, in order to respond to the needs expressed in the SDGs. That is to say, it is necessary to train both the youth and the future teachers the technological tools and techniques for their use of those contents, in order to provide society with those professional abilities.

In the case of audiovisual education, known as the link between education and Information and Communication Technologies (ICTs), which is the object of study, the widespread use of audiovisual practices has led to alterations in classroom practices. This, however, does not generally imply that the underlying ends or meaning of audiovisual education have changed. This is no accident: there are continual vested interests in capitalizing on the need for tool-based technological innovation rather than skills-which are more difficult to turn into consumer products [6]. This explains the importance of introducing audiovisual practice adequately into all educational spheres [7].

That is why studies on the tools and methodologies linked to audiovisual education point to the need to teach people to be critical of audiovisual media as well as to build technical skills [8-10]. Indeed, we are today facing the problem of the exploitation of new technologies that use digital noise and glitter to cover up the true depth of the crisis of schools' relations with society [11].

From the perspective of the SDGs, it is important to consider an audiovisual education that provides all students with both technical and theoretical knowledge, and therefore it is essential to determine how future teachers perceive the socio-educational purposes of using audiovisual tools in order to develop this sustainable lifestyle, as well as an egalitarian, diversified and peaceful promotion of it. In this sense, it is important to know the perceptions of these students regarding the concept of communication.

The scientific literature on audiovisual education has centered on three major points: (a) the analysis of how new generations of children and young people use technology; (b) methodological approaches to audiovisual education in the classroom; and (c) the socio-educational objectives of visual literacy.

Regarding the analysis of uses by children and young people, it is worth noting that the fracture between new forms of socialization and educational institutions is leading to generational identity becoming synonymous with technological identity [12,13]. That is, a belief is circulating in society that the so-called digital natives possess the skills necessary to function as critical citizens in postmodern society. This belief goes against the fact that a number of studies have demonstrated the gap between the use of technology and the ability to create knowledge using technology [14]. Graduates point to the limitations in their training [15]. In addition, even teachers themselves recognize that while they feel competent working with innovative methodologies, they do not undergo specific and continuous training on the subject of technology usage and lack the resources necessary to implement pedagogical-technological practices [16].

With regard to the methodological approach to audiovisual education in the classroom, a gap has now emerged between the treatment of audiovisual tools in educational spheres and current forms of communication [17,18]. At this stage, it is essential to consider the highly superficial way in which educational innovation proposals are contextualized in the classroom [19]. More importantly, the literacy model of compulsory artistic education has conditioned the curriculum in recent years [20], transforming the teaching-learning process [21,22].

For this reason, major educational practice proposals have been conditioned in recent decades by a concept of visual literacy that focuses on observing and examining images, with the objective of generating self-sufficient observers [23]. In other words, new forms of communication necessarily require 
including and integrating students' perspectives, moving them away from a totally passive role [24]. In order to interpret and represent students' experiences, based on their own perspectives and identities [25], one must turn towards a daily knowledge obtained by students, making their voice an essential part of the educational curriculum [26,27].

With regard to the socio-educational objectives of visual literacy, it should be noted that audiovisual experience plays a crucial part in the construction of personal identities: the media influences how representations of identities are built, and they do so by addressing them not only as consumers but also through the wide range of creator and viewer mediations [28].

Based on the above, and taking into account the Sustainable Development Goal 4, the objective of this study is to analyze future schoolteacher perceptions regarding audiovisual uses in education. The aim was to learn about the educational models and epistemological assumptions underlying their approach to audiovisual education in order to detect their training needs and contribute to filling the gap between school and new forms of communication.

In itself, the aim is to analyze the methodological positions of future teachers with regard to audiovisual education.

Specifically, the objectives were:

A. To define students' perceptions of audiovisual education and their own training on the subject

B. To analyze future schoolteachers' methodological positioning regarding audiovisual education

C. To describe the socio-educational ends assigned by students to the use of audiovisual tools

D. To observe whether there are statistically significant differences between the sexes in the students' perceptions of audiovisual education and their training, the methodological positions and the socio-educational purposes assigned to it.

E. To describe students' perceptions of the concept of communication.

\section{Materials and Methods}

\subsection{Scope}

An online survey was conducted among students of the Faculty of Education of the University of Alicante on 15, 16 and 17 June 2020. The total sample was 278 students enrolled in their fourth year of the Preschool and Primary Education degree. A total of $78.42 \%$ students were female and $21.58 \%$ were male.

The study used a causal non-probability sampling based on feasibility and accessibility criteria. All students had already completed the subject under study, as well as Educational Internships in Preschool and Primary Education schools. We thus considered that they represented a valuable descriptive sample and that they would allow us to learn about their perceptions and detect limitations and needs, both in their theoretical training at the university and through the knowledge they put into practice during their internships in their respective schools.

\subsection{Instrument for Collecting Information}

Perceptions of audiovisual education (PEAV): This instrument was a Likert-type questionnaire that includes 5 response options $(1=$ Strongly disagree; $5=$ Strongly agree $)$. The questionnaire was structured around 3 major blocks: I Teacher Training Needs; II Social and Current Objectives; and III Educational Objectives. In turn, these items were grouped into various categories (see Appendix A Table A1).

The internal consistency for the entire questionnaire was adequate for the present study $(\alpha=0.84)$.

Perceptions of the meaning of communication (PMC): This was a questionnaire with 5 items about definitions of communication. The participant needed to choose the answer that comes closest to his/her reality of meaning (see Appendix A Table A2). 


\subsection{Procedure}

First, the participants were told about the objective of the study. Once informed, they were asked to collaborate, explaining that their participation was voluntary and that their anonymity was guaranteed. An explanation was then given on how to respond to the questionnaire, which was administered online through the Google Forms tool. The researchers provided them with a link that gave them access to the test once it was launched and the test lasted for around $15 \mathrm{~min}$.

\subsection{Data Design and Analysis}

The chosen method was an empirical-analytical design of a transversal quantitative-descriptive nature, using two ad-doc questionnaires [29-31]. This type of study allowed us to quantify research through an ex-post-facto design [32,33], enabling us to describe reality, analyze relationships, categorize, simplify and organize the variables that compose the object of study because objective numerical data can be obtained [34].

The internal consistence was observed from Cronbach's alpha coefficient.

Participants' perceptions were collected by performing descriptive statistical analyses such as frequencies and percentages, averages, medians and standard deviations. An analysis of variance (ANOVA) was also carried out to observe statistically significant differences between the sexes. The magnitude of the differences was calculated with Cohen's [35], which contemplates a high effect size for scores equal to or greater than 0.80 , a moderate size for scores between 0.50 and 0.79 , and a small effect size for scores between 0.20 and 0.49 .

Participants' perceptions were collected by performing descriptive statistical analyses such as frequencies and percentages, averages, medians and standard deviations. The analyses were conducted using the SPSS 24.0 software.

\section{Results}

Upon analysis of the assessments made by future schoolteacher of their audiovisual training (Table 1), we found that the response scoring the highest percentage across all items-learning about language, tools, critical analyzes and audiovisual tool use-was "Slightly agrees", with percentages ranging from $29.90 \%$ to $41.70 \%$. A very low percentage, between $1.10 \%$ and $7.20 \%$ provided a "Strongly agreed" rate. It is noteworthy that $23 \%$ of participants felt quite "ready to use audiovisual media in classrooms in the future".

Table 1. Perceptions of teacher training needs.

\begin{tabular}{cccccccccc}
\hline Category & Item & DVS \% & SA \% & A \% & AQS\% & AVS\% & A & M & SD \\
\hline \multirow{4}{*}{ Teacher training } & 1 & 22.70 & 41.70 & 25.90 & 8.30 & 1.40 & 1.00 & 1.24 & 0.94 \\
& 2 & 17.30 & 40.60 & 25.20 & 15.80 & 1.10 & 1.00 & 1.43 & 0.98 \\
& 3 & 25.20 & 36.0 & 27.70 & 9.40 & 1.80 & 1.00 & 1.27 & 0.99 \\
& 4 & 8.30 & 29.90 & 31.70 & 23.0 & 7.20 & 1.00 & 1.91 & 1.14 \\
\hline
\end{tabular}

Note: DVS = Disagree Very Strongly; SA = Slightly Agree; A = Agree; AQS = Agree Quite Strongly; AVS = Agree Very Strongly; $\mathrm{M}=$ Mean; $\mathrm{A}=$ Average; $\mathrm{SD}=$ Standard Deviation.

Table 2 shows the means and averages of students' assessments of educational ends based on different methodological approaches.

The future schoolteachers believed that audiovisual media facilitates content transmission. Specifically, $39.20 \%$ very strongly agreed that it was important to "view films with enriching subject matter", and $30.20 \%$ very strongly agreed that it was important to "show audiovisual products that were different from those consumed by the mass media".

Nevertheless, they still considered it was more important to develop capabilities to understand reality, and analyze the audiovisual language. In particular, the future schoolteachers very strongly agreed that "audiovisual work enables addressing relevant problems in society" $(46.80 \%)$ 
and that "classroom practice is important to allow pupils to function effectively in the information society" $(51.80 \%)$.

Table 2. Educational ends and methodological approaches.

\begin{tabular}{cccccccccc}
\hline Categories & Items & DVS $\%$ & SA $\%$ & A\% & AQS\% & AVS\% & A & M & SD \\
\hline & 9 & 1.10 & 1.80 & 20.10 & 37.80 & 39.20 & 3.00 & 3.12 & 0.87 \\
Facilitate content transmission & 10 & 0.70 & 3.60 & 30.20 & 35.30 & 30.20 & 3.00 & 2.91 & 0.90 \\
& 11 & 1.10 & 11.50 & 37.10 & 31.70 & 18.70 & 4.00 & 3.55 & 0.96 \\
& 12 & 1.10 & 4.30 & 33.50 & 39.60 & 21.60 & 3.00 & 2.76 & 0.88 \\
\hline $\begin{array}{c}\text { Develop skills to understand } \\
\text { reality, and analyze the } \\
\text { audiovisual language }\end{array}$ & 13 & 0.40 & 3.20 & 11.50 & 38.10 & 46.80 & 4.00 & 4.30 & 0.82 \\
\hline $\begin{array}{c}\text { Promote creativity and } \\
\text { artistic expression }\end{array}$ & 15 & 1.40 & 13.70 & 39.90 & 32.40 & 12.60 & 4.00 & 3.41 & 0.93 \\
\hline
\end{tabular}

Note: DVS = Disagree Very Strongly; SA = Slightly Agree; A = Agree; AQS = Agree Quite Strongly; AVS = Agree Very Strongly; $\mathrm{M}=$ Mean; $\mathrm{A}=$ Average; $\mathrm{SD}=$ Standard Deviation.

Furthermore, about one third of the participants considered it quite important $(38.50 \%)$ or very important $(31.70 \%)$ to promote creativity and artistic expression in the classroom through "audiovisual creation".

With regard to future schoolteachers' perceptions regarding the social and current ends of Audiovisual Education, the vast majority quite strongly or very strongly agreed that "knowing how to analyze the language of image and cinema increases awareness"-AQS $=54.30 \%$ and AVS 35.30\%-as well as that "knowing the history of cinema helps us to better understand audiovisual contents today"-AQS $=48.90 \%$ and $28.80 \%$. Similarly, participants agreed quite strongly that audiovisual media helps to express ourselves in everyday life. Specifically, future schoolteachers agreed quite strongly or very strongly that "audiovisual education gives us the opportunity to express ourselves and make discourses visible" - $56.10 \%$ and $33.10 \%$, respectively —and that "knowing about audiovisual tools leads to skills that are necessary in today's world" $-52.90 \%$ and $33.10 \%$ respectively-as shown in Table 3.

Table 3. Social and current ends.

\begin{tabular}{cccccccccc}
\hline Categories & Items & DVS $\%$ & SA $\%$ & A\% & AQS $\%$ & AVS $\%$ & A & M & SD \\
\hline Audiovisual media for & 5 & 0.00 & 2.50 & 7.90 & 54.30 & 35.30 & 3.00 & 3.22 & 0.70 \\
understanding current affairs & 6 & 0.40 & 1.10 & 20.90 & 48.90 & 28.80 & 3.00 & 3.05 & 0.76 \\
\hline Audiovisual media to express & 7 & 0.00 & 1.10 & 9.70 & 56.10 & 33.10 & 3.00 & 3.21 & 0.65 \\
ourselves in everyday life & 8 & 0.00 & 0.70 & 13.30 & 52.90 & 33.10 & 3.00 & 3.18 & 0.68 \\
\hline
\end{tabular}

Note: DVS = Disagree Very Strongly; SA = Slightly Agree; A = Agree; AQS = Agree Quite Strongly; AVS = Agree Very Strongly; $\mathrm{M}=$ Mean; $\mathrm{A}=$ Average; $\mathrm{SD}=$ Standard Deviation.

Among the perceptions about the relevance of Audiovisual Education in future teachers, statistically significant differences stand out in the categories of Needs and Teacher Training, and in the Educational Objectives and Methodological Approaches, specifically in facilitating the transmission of contents and in developing skills to understand reality, to proceed and to be critical (see Table 4).

Specifically, it is men who consider that they have received a greater teacher training and feel prepared, observing a moderate magnitude of the differences $(d=0.34)$. Likewise, with a moderate magnitude of the differences $(d=0.25)$, it is women who estimate, to a greater extent, that Audiovisual Education facilitates the transmission of knowledge, as well as that Audiovisual Education develops capacities to understand reality, to proceed and to be critical $(d=0.43)$.

On the other hand, the results show that $46 \%$ of the future teachers consider that communication is a two-way process that has both emotional and cognitive elements and that it occurs both verbally and non-verbally. Likewise, $45.2 \%$ think that communication is the process of democratic social interaction 
based on the exchange of symbols through which human beings voluntarily share their experiences under conditions of free and equal access, dialogue and participation (see Figure 1).

Table 4. Means, standard deviations and effect sizes for perceptions of the importance of audiovisual education in future teachers.

\begin{tabular}{cccccccccc}
\hline & \multirow{2}{*}{ Levine Test } & \multicolumn{2}{c}{ Women } & \multicolumn{2}{c}{ Men } & \multicolumn{3}{c}{$\begin{array}{c}\text { Statistical Significance and } \\
\text { Magnitude of Differences }\end{array}$} \\
\hline Dimensions & $\boldsymbol{F}$ & $\boldsymbol{p}$ & $\mathbf{M}$ & SD & M & SD & $\boldsymbol{t}$ & $\boldsymbol{p}$ & $\boldsymbol{d}$ \\
\hline A & 0.001 & 0.985 & 5.60 & 3.27 & 6.72 & 3.22 & -2.37 & 0.018 & 0.34 \\
B & 0.098 & 0.755 & 5.71 & 1.18 & 5.45 & 1.26 & 1.49 & 0.136 & - \\
C & 0.665 & 0.416 & 7.15 & 1.23 & 7.11 & 1.22 & 0.25 & 0.800 & - \\
D & 2.261 & 0.134 & 12.52 & 2.75 & 11.72 & 2.40 & 2.05 & 0.041 & 0.25 \\
E & 0.105 & 0.746 & 12.25 & 1.93 & 11.41 & 1.97 & 2.97 & 0.003 & 0.43 \\
F & 2.470 & 0.117 & 3.08 & 0.89 & 3.04 & 0.798 & 0.28 & 0.780 & - \\
\hline
\end{tabular}

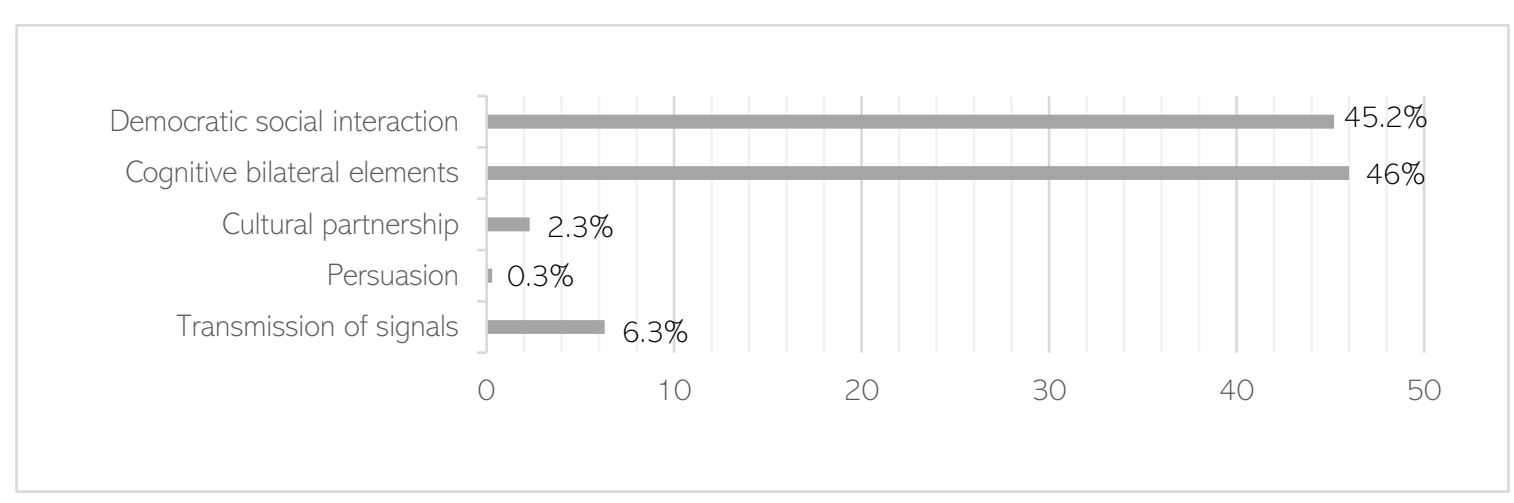

Figure 1. Future teachers' perceptions on the meaning of Communication.

\section{Discussion}

The results of this study shed light on future schoolteachers' perceptions of audiovisual education and communication, as well as the differences in perception between the sexes. These indicate that the communication is about cognitive bilateral elements and democratic social interaction. Similarly, they consider the use of classroom audiovisual work in order to address social issues. Nevertheless, future schoolteachers recognize the need not only to learn how to use audiovisual tools, but also to acquire an in-depth knowledge of theoretical foundations and to be sufficiently trained to form critical analyses of their usage, which are considered valuable to be able to achieve educational improvements. These results show a significant importance in the light of SDG4 by 2030, since these perceptions of future teachers indicate the strengths and weaknesses of how Audiovisual Education is being carried out in universities and gives rise to the design of those strategies to be followed for the improvement of educational quality.

It should be recalled that one of the goals set in the SDG4 for 2030 is to ensure that all girls and boys complete free, equitable and quality primary and secondary education, leading to relevant and effective learning outcomes [4]. In today's world, we cannot forget the relevance of social media and technology use, and its role in achieving sustainable education [36]. In this regard, we consider it to be essential to deepen the state of the art on the teaching-learning process of technological training in countries like Spain. Keeping in mind this study's first objective, which was to define students' perceptions of audiovisual education and of their own training on the subject, and under the findings observed, it is worth noting the difference between the importance attached to audiovisual education and future schoolteachers' conception of their own training. Most future schoolteachers considered audiovisual education at school to be necessary and important, but when assessing the extent of their own training on the use of audiovisual tools, fewer positive results were found. 
Generally, participants claimed they had been trained to a certain degree, but not sufficiently to feel competent regarding the subject's theoretical foundations, usage and critical analysis. The results obtained are consistent with claims that both teacher training and teacher practices are limited and insufficient, even today $[9,16,17]$. This implies that a new educational approach is required in higher education, directed towards "extending education to the electronic domain"— $e$-education—as was already advanced over a decade ago by Echeverría Ezponda [12].

In this context, it should be noted that the SDG4 points out the need to "ensure that all students acquire the knowledge and skills necessary to promote sustainable development" [4]. In this regard, in order to address this need, one of the tasks suggested by the UN (2015) is based on increasing worldwide scholarships for students to enrol in universities, professional, technical and scientific training, as well as training on the use of ICTs. It is therefore necessary to take into account several sectors to which attention should be paid. On the one hand, greater training in audiovisual matters should be implemented for university professors with the aim of instructing future teachers. Consequently, this would make those future teachers feel more capable of not only working with audiovisual media but also of instructing students in ICT at the different stages of compulsory education.

In reference to the methodological positions of future schoolteachers with regard to audiovisual education, it should be noted that these are related to the objective of the 2030 Agenda concerning the need to significantly increase the number of young people and adults who acquire the necessary skills related to technological capabilities among others.

In the results obtained, we can highlight the emphasis was both on content transmission and skill development, encouraging creativity. However, within these blocks, future schoolteachers valued the methodologies in which students are passive. They supported practices that center on audiovisual contents because they present themes of interest or for their subsequent analysis, such as viewing films, among other examples.

Students consider it important to promote creativity by producing audiovisual contents in the classroom, although they still believe it is more important that audiovisual education in the classroom be directed towards addressing problems in society. One finding was compatible with that of Marfil-Carmona and Chacón [37] who found that one major learning subject of interest was audiovisual creation of both short films and animation or stop-motion videos, as opposed to other more traditional art genres such as drawings and paintings, among others. These results reveal that on the one hand, students are aware of the importance of audiovisual work in the classroom, above all, for socio-educational ends. However, despite being aware of the subjects they wish to teach in the classroom, as observed above, future schoolteachers also requested to learn about the theory and use of tools in their own training. This suggests, as indicated by Çebi and Reisoğlu [9], that if university students-i.e., future schoolteachers-play a more passive role, it may be because of a lack of skills. If they felt they were sufficiently trained, they may include more active production among their educational ends. It should be clearly stressed in this second objective that if we turn it down to the purpose of the audiovisual, the future teachers do understand this tool as one with a social purpose. However, if we open the range of the audiovisual as a means of communication, other productive areas are not considered, as can be observed from the fourth objective marked in this study.

Taking into account the proposals of these future schoolteachers, we should consider the fact that audiovisual creation in the classroom can be highly useful and motivating. The design must, however, be very well-thought out, especially regarding the informative side. Indeed, there is a risk of distorting the meaning of students' participation and creation, for example letting students manage the camera without exploring their opinions and views [38]. In addition, if the objective is also to work on social usages or address social issues on the theme of youth, as indicated by the participants, procedural design and the informative approach (that is, transmission) play an even more essential role.

The responses analyzed in this study are consistent with those obtained by Black and Browning [23] when they point out that audiovisual tools can support academic success, but without adequate training 
on audiovisual use, audiovisual practices turn into mere reproduction, that is, they do not bring any added value to the teaching-learning process.

The answers revealed an approach to audiovisual education based on a traditional knowledge transmission perspective. We can thus assert that audiovisual use in classrooms contrasts with new forms of communication today [17].

Thus, audiovisual education needs to be addressed in a new way that allows us to expand the concept of literacy, since qualitative improvements to teaching cannot be understood as such today if they do not tend, aspire and act towards educating citizens able to function autonomously and responsibly and in a critical and creative way [39].

The results also show students' interest in using audiovisual tools with respect to media creation and appropriation in relation to today's society and environment. For this, there is an understanding that future schoolteachers' audiovisual training must include participatory approaches.

In this regard, in the socio-educational purposes that the students attribute to the use of audiovisual tools, according to the need to "ensure that all students acquire the necessary knowledge and skills to promote sustainable development" (UN, 2015, p. 19), it is observed in the results the need to train technically and theoretically all students in order to develop that sustainable lifestyle and that egalitarian, diversified and peaceful promotion. Hence, students considered it quite important to learn about image analysis, the history of cinema and audiovisual tools.

They also quite strongly agreed that such training could provide the opportunity to express oneself and give visibility to discourses, i.e., help people to be critical and thoughtful on a day-to-day basis. These results are compatible with that of previous studies, which showed a predominating preference of students for training skills of an analytical, reflective, theoretical and systematic nature [21]. However, authors such as Çebi and Reisoğlu [9] argue that shortcomings observed in teacher training programs regarding technical and digital content development may be increasing that tendency towards passive literacy.

Here again it is necessary to consider the objectives of SDG4 (2015) and teacher training. In fact, another goal proposed for 2030 seeks to "substantially increase the supply of qualified teachers, including through international cooperation for teacher training in developing countries, especially least developed countries and small island developing States" (UN, 2015, p. 20). This is where the supply of qualified teachers can be offered, provided that teachers are qualified in all areas.

On the other hand, with regard to the perceptions of future teachers about Visual Education, the fourth objective of the study, determined the analysis of the differences observed by sex. Within these differences, men felt they had received more teacher training and felt more prepared than women. Under these findings, the accuracy of the self-concept must be taken into account. Several studies show that women tend to underestimate themselves in this area [40]. Specifically, Herbst [41] found how women were rated higher by their peers than by their own self-evaluation, while men significantly overrated themselves when compared to being evaluated by their peers [41]. These results warn of the need to work on both self-esteem and self-confidence in the classroom to build a realistic self-concept among all students regardless of gender.

Likewise, the findings of the present study show that it is women who are most appreciative of the idea that Audiovisual Education facilitates the transmission of knowledge and develops skills to understand reality, to proceed and to be critical. In other words, it seems that women are more aware of the educational purposes and methodological approaches that Audiovisual Education can provide. Taking into account the fact that self-concept is linked to performance [42], perhaps it is this awareness of the educational purpose of Audiovisual Education that provides, at the same time, a lesser self-concept regarding preparation in this field. In other words, the results found could be indicating that women require more training because they are more aware of the educational importance of the audiovisual and need to feel more prepared to obtain a beneficial performance.

Finally, regarding the students' perception of the concept of communication, two percentages are observed that hold almost half of the responses. On the one hand, $46 \%$ of the future teachers 
think that communication is a bilateral process that has both emotional and cognitive elements and that it occurs both verbally and non-verbally. On the other hand, $45.2 \%$ think that communication is the process of democratic social interaction based on the exchange of symbols in which human beings voluntarily share their experiences under conditions of free and equal access, dialogue and participation. This is in line with the objective of the SDG4, which indicates the need to "ensure that all learners acquire the knowledge and skills to promote [...] the adoption of sustainable lifestyles, human rights, gender equality, the promotion of a culture of peace and nonviolence, global citizenship and the appreciation of cultural diversity and of culture's contribution to sustainable development" (UN, 2015, p. 19).

Thus, audiovisual media become valuable to achieve this goal, especially considering that this democratic social interaction, this exchange of symbols between humans and the communication, both emotional and cognitive, not only takes place face to face, but also needs ICT and social networks to travel to the other side of the world from your workplace or your own home.

Likewise, these means are necessary to establish new sustainable business relationships, learn about other cultures and obtain that globalized vision. It is very remarkable that only $2.3 \%$ of future teachers, under the findings observed, consider communication as the exchange of messages involving cultural co-participation.

Here is where we can see that the students, even though they are active participants in social networks and audiovisual media, and taking into account their purposes and utilities, do not consider these media as a tool for cultural co-participation. This could be due to the fact that they have not observed all the possibilities that this encompasses. In this sense, it is necessary to take into account one of the objectives that the United Nations Development Program [43] is reviewing, referring to the development of inclusive and sustainable industrialization that aims to "strengthen the means of implementation and revitalize the Global Partnership for Sustainable Development". Hence, the need to implement the idea of communication under that free, equal and participatory access, but where there is room for that cultural co-participation, and where the audiovisual media can be an essential tool. In fact, at present, in times of a pandemic, it is not merely a useful tool but an essential one in the educational, social, labor and cultural spheres [44-46].

Audiovisual experience, in an instrumental sense, involves working not only on tool use, but also on collective awareness [47]. That is why people who facilitate this type of learning must engage in a prior reflection on its socio-communicative foundations. This does not imply, however, any necessary prior study of the community that uses participatory audiovisual tools.

\section{Conclusions}

The study was based on a broad sample of participants and can be considered to be fairly generalizable. It would be necessary, however, to analyze perceptions in other Faculties of Education, take into account previous studies, or even perform a comparative study by replicating the study in other countries. It would also be desirable to address a more extensive and balanced study between men and women in the educational field to verify any possible gender differences, taking into account from this study that participation has been mostly women, so in this particular case, there may be a certain bias.

Moreover, although a transversal quantitative-descriptive methodology was used in this study - using an ad-doc questionnaire - in light of the results, it would seem necessary to apply qualitative research using the focus group technique with semi-structured interviews. This way, it would be possible to obtain further underlying information and a more accurate assessment of perceptions of the subject. We must remember that self-reporting presents the risk of social desirability $[48,49]$.

However, despite the limitations observed, the results of this study have practical implications regarding how audiovisual training based on creative and participatory approaches can meet future 
schoolteachers' current needs. Such training would enable addressing relevant social issues based on students' daily interests and knowledge.

In the same way, the results of this study show how future teachers require more training in audiovisuals in order to feel more capable of carrying out their work in the future in their Preschool and Primary Education classrooms. At the same time, it is women who require more training than men, which reveals two interrelated aspects based on a lesser self-concept in women, but also a greater awareness of the importance of the educational purposes required by audiovisuals. For this reason, it is necessary to rethink and design an education for teachers with a greater audiovisual load that guarantees quality education for sustainable development, while at the same time giving it the importance of audiovisuals as an educational goal, developing this awareness in all students. Also, on the other hand, it is considered necessary that these adaptations allow us to raise the self-concept and self-confidence of the students, independently of the sex they belong to.

Therefore, the Faculties of Education are urged to expand training in Audiovisual Education, also taking into account that likewise, the students would be trained in its use and training in order to be able to establish qualified teachers and students that are well prepared for their daily social, productive and emotional life.

After reviewing the SDG4, students need to be critical of audiovisual media production, which implies a shift from a consumer role and/or critical role, to the role of creators of audiovisual content adopting a participatory and collective approach.

Author Contributions: Conceptualization, A.O.-B. and R.P.E.-F.; methodology, R.P.E.-F.; software, M.P.A.-F.; formal analysis, R.P.E.-F.; investigation, A.O.-B. and M.P.A.-F.; resources, R.P.E.-F.; data curation, A.O.-B.; writing-original draft preparation, A.O.-B.; writing-review and editing, R.P.E.-F. and M.P.A.-F.; visualization, A.O.-B., R.P.E.-F. and M.P.A.-F.; supervision, A.O.-B., R.P.E.-F. and M.P.A.-F.; project administration, A.O.-B., R.P.E.-F. and M.P.A.-F. All authors have read and agreed to the published version of the manuscript.

Funding: This research received no external funding.

Conflicts of Interest: The authors declare no conflict of interest.

\section{Appendix A}

Table A1. PEAV categories and items.

\begin{tabular}{|c|c|c|}
\hline Block & Categories & Items \\
\hline I Teacher Training Needs & (A) Teacher training & $\begin{array}{l}\text { 1. I have received sufficient information } \\
\text { about audiovisual language. } \\
\text { 2. I dispose of sufficient information } \\
\text { about different audiovisual tools to } \\
\text { work on in the classroom. } \\
\text { 3. I have been sufficiently trained on the } \\
\text { possibilities of critical media education. } \\
\text { 4. I am prepared to use audiovisual } \\
\text { media in the classroom in the future. }\end{array}$ \\
\hline \multirow[t]{2}{*}{ II Social and Current Objectives } & $\begin{array}{l}\text { (B) Audiovisual media to } \\
\text { understand current affairs }\end{array}$ & $\begin{array}{l}\text { 5. Knowing how to analyze the } \\
\text { language of image and cinema } \\
\text { increases our awareness. } \\
\text { 6. Knowing the history of cinema } \\
\text { (movies, authors, genres, etc.) helps us } \\
\text { to better understand current } \\
\text { audiovisual contents. }\end{array}$ \\
\hline & $\begin{array}{l}\text { (C) Audiovisual media to express } \\
\text { ourselves in everyday life }\end{array}$ & $\begin{array}{l}\text { 7. Audiovisual education gives us the } \\
\text { opportunity to express ourselves and } \\
\text { make discourse visible. } \\
\text { 8. Knowing about audiovisual tools } \\
\text { contributes to building to the skills } \\
\text { necessary for today's world. }\end{array}$ \\
\hline
\end{tabular}


Table A1. Cont.

\begin{tabular}{|c|c|c|}
\hline Block & Categories & Items \\
\hline \multirow{3}{*}{$\begin{array}{l}\text { III Educational Objectives and } \\
\text { Methodological Approaches }\end{array}$} & $\begin{array}{l}\text { (D) Facilitates the transmission } \\
\text { of content }\end{array}$ & $\begin{array}{l}\text { 9. Viewing of films that are enriching } \\
\text { because of their subject (history, values, } \\
\text { literature, etc.). } \\
\text { 10. Show audiovisual products other } \\
\text { than those consumed by the mass media. } \\
\text { 11. It is important that our students } \\
\text { know about references of } \\
\text { the history of cinema } \\
\text { 12. Analysis of audiovisual language } \\
\text { (images, scenes, sequences, script...). }\end{array}$ \\
\hline & $\begin{array}{l}\text { (E) Developing capacities to } \\
\text { understand reality, and analyze } \\
\text { the audiovisual language }\end{array}$ & $\begin{array}{l}\text { 13. Audiovisual work must allow us to } \\
\text { address socially relevant problems. } \\
\text { 14. Classroom practice is important to } \\
\text { allow our students to be operational in } \\
\text { the information society. } \\
\text { 15. It is necessary to perform } \\
\text { audiovisual work following } \\
\text { cinematography procedures } \\
\text { with students. }\end{array}$ \\
\hline & $\begin{array}{l}\text { (F) Encourage creativity and } \\
\text { artistic expression }\end{array}$ & $\begin{array}{l}\text { 16. Audiovisual creation processes } \\
\text { in classrooms. }\end{array}$ \\
\hline
\end{tabular}

Table A2. PMC items.

\begin{tabular}{c} 
Block \\
$\begin{array}{l}\text { 1. Transmission of signals by means of a code common to both the transmitter } \\
\text { and the receiver. }\end{array}$ \\
2. The primary purpose of communication is persuasion, since people control each \\
other through communication. \\
3. Communication is the exchange of messages that involve cultural sharing. \\
4. Communicating refers to a two-way process that has both emotional and cognitive \\
elements and occurs in both verbal and non-verbal ways. \\
$\begin{array}{r}\text { 5. Communication is the process of democratic social interaction based on the } \\
\text { exchange of symbols by which human beings voluntarily share their experiences } \\
\text { under conditions of free and equal access, dialogue and participation. }\end{array}$ \\
\hline
\end{tabular}

\section{References}

1. Lockee, B.B.; Wang, F. Visual Arts Education. In Handbook of Research on Educational Communications and Technology; Spector, J.M., Merrill, M.D., Elen, J., Bishop, M.J., Eds.; Springer: New York, NY, USA, 2014; pp. 583-590.

2. Nicolaou, C.; Matsiola, M.; Kalliris, G. Technology-Enhanced Learning and Teaching Methodologies through Audiovisual Media. Educ. Sci. 2019, 9, 196. [CrossRef]

3. Frau-Meigs, D.; Hibbard, L. Education 3.0 and Internet Governance: A New Global Alliance for Children and Young People's Sustainable Digital Development; The Centre for International Governance Innovation and Chatham House: Ottawa, QC, Canada, 2016.

4. United Nations. Resolution Adopted by the General Assembly on 25 September 2015. Transforming Our World: The 2030 Agenda for Sustainable Development. Available online: https:/www.un.org/ga/search/ view_doc.asp?symbol=A/RES/70/1\&Lang=E (accessed on 1 September 2020).

5. Frau-Meigs, D. Media literacy and human rights: Education for sustainable societies. Croat. J. Commun. Psychol. 2008, 5, 145-157.

6. Esteve-Faubel, J.M.; Oller Benítez, A. Hacia un uso de las herramientas audiovisuales para la transformación social: Análisis de las percepciones de los futuros docentes. In Investigación e Innovación en la Enseñanza Superior: Nuevos Contextos, Nuevas Ideas; Roig-Vila, R., Ed.; Octaedro: Barcelona, Spain, 2019; pp. 1107-1115.

7. Gimeno Sacristán, J. La Educación que aún es Posible: Ensayos Acerca de la Cultura para la Educación; Morata: Madrid, Spain, 2005; p. 184. 
8. Ávalos, C.; Pérez-Escoda, A.; Monge, L. Lean Startup as a Learning Methodology for Developing Digital and Research Competencies. J. New Approaches Educ. Res. 2019, 8, 227-242. [CrossRef]

9. Çebi, A.; Reisoğlu, İ. Digital Competence: A Study from the Perspective of Pre-service Teachers in Turkey. J. New Approaches Educ. Res. 2020, 9, 294-308. [CrossRef]

10. Romero-García, C.; Buzón-García, O.; de Paz-Lugo, P. Improving Future Teachers' Digital Competence Using Active Methodologies. Sustainability 2020, 12, 7798. [CrossRef]

11. Martín-Barbero, J. Ciudad educativa: De una sociedad con sistema educativo a una sociedad de saberes compartidos. In Educación Expandida; Zemos 98, 2012; pp. 103-129. Available online: http://www.zemos98. org/descargas/educacion_expandida-ZEMOS98.pdf (accessed on 1 September 2020).

12. Echeverría Ezponda, J. Expandir la educación al tercer entorno. In Educación Expandida; Zemos 98, 2012; pp. 167-181. Available online: http://www.zemos98.org/descargas/educacion_expandida-ZEMOS98.pdf (accessed on 1 September 2020).

13. Freire, J. Monográfico "Cultura digital y prácticas creativas en educación”. Univ. Knowl. Soc. J. 2009, 6, 1-6.

14. Ito, M.; Horst, H.A.; Bittanti, M.; Herr Stephenson, B.; Lange, P.G.; Pascoe, C.; Robinson, L. Living and Learning with New Media: Summary of Findings from the Digital Youth Project. International Encyclopedia of Civil Society; The MIT Press: Cambridge, UK, 2009.

15. Gardner, H.; Davis, K. Hablemos de tecnología. In La generación APP: Cómo los Jóvenes Gestionan su Identidad, su Privacidad y su Imaginación en el Mundo Digital; Gardner, H., Davis, K., Eds.; Paidós: Barcelona, Spain, 2014; pp. 29-46.

16. López Belmonte, J.; Pozo Sánchez, S.; del Pino Espejo, M. Projection of the Flipped Learning Methodology in the Teaching Staff of Cross-Border Contexts. J. New Approaches Educ. Res. 2019, 8, 184-200. [CrossRef]

17. Abac1, O. An Evaluation of Teacher Candidates' Opinions about Art Education and Form-meaning Relationship. Procedia Soc. Behav. Sci. 2015, 174, 1791-1797. [CrossRef]

18. Esteban, F.O.; Salvador Jardí, M. Globalización y cambio educativo. In Sociología de la Educación; Beltrán Llavador, J., Hernàndez i Dobon, F.J., Eds.; McGraw Hill: Madrid, Spain, 2011; pp. 255-268.

19. Hernández Rojas, G.; Díaz Barriga, F. Una mirada psicoeducativa al aprendizaje: Qué sabemos y hacia dónde vamos. Sinéctica Rev. Electrónica Educ. 2013, 40, 1-19.

20. Castañeda Quintero, L.J. Suelo y sol: Más pensamiento y contexto para la innovación educativa. Boletín Inst. Libre Enseñanza 2016, 104, 37-50.

21. Barbosa Granados, S.; Amariles Jaramillo, M. Learning Styles and the Use of ICT in University Students within a Competency-Based Training Model. J. New Approaches Educ. Res. 2019, 8, 1-6. [CrossRef]

22. Moreno González, A. La mediación Artística. Arte para la Transformación Social, la Inclusión Social y el Desarrollo Comunitario; Octaedro: Barcelona, Spain, 2016; p. 159.

23. Black, J.; Browning, K. Creativity in Digital Art Education Teaching Practices. Art Educ. 2011, 64, $19-34$. [CrossRef]

24. Acaso López Bosch, M. La Educación Artística no son Manualidades: Nuevas Prácticas en la Enseñanza de las Artes y la Cultura Visual; Los Libros de la Catarata: Madrid, Spain, 2009; p. 239.

25. Bacher, S. Tatuados por los Medios: Dilemas de la Educación en la era Digital; Paidós: Buenos Aires, Argentina, 2009; p. 178.

26. Cook-Sather, A. Resisting the Impositional Potential of Student Voice Work: Lessons for liberatory educational research from poststructuralist feminist critiques of critical pedagogy. Discourse Stud. Cult. Politics Educ. 2007, 28, 389-403. [CrossRef]

27. Martínez Rodríguez, J.B. El currículo como espacio de participación: La democracia escolar ¿es posible? In Saberes e Incertidumbres Sobre el Currículum; Gimeno Sacristán, J., Ed.; Morata: Madrid, Spain, 2010; pp. 162-179.

28. Gutiérrez-Sánchez, J.D.; Morcillo Loro, V.; Diz Casal, J. Repensando el Currículum desde una visión integrada: “El Humanities Curriculum Project" para una escuela democrática. Int. J. New Educ. 2018, 1, 78-96.

29. Cerdeiro, C.I. La infancia televidente. Consumos culturales, experiencias de aprendizaje y construcción de representaciones. Diálogos Pedagógicos 2013, 11, 75-92.

30. Cohen, L.; Manion, L.; Morrison, K. Research Methods in Education, 8th ed.; Routledge: London, UK, 2018 ; p. 916.

31. Guzmán Arredondo, A. El Enfoque de Métodos Mixtos: Una Nueva Metodología en la Investigación Educativa; Idea Editorial: Chihuahua, Mexico, 2015; p. 69. 
32. Mateo Andrés, J. La investigación ex post-facto. In Metodología de la Investigación Educativa; La Muralla: Madrid, Spain, 2004; pp. 196-230.

33. McMillan, J.H.; Schumacher, S. Research in Education: A Conceptual Introduction, 5th ed.; Longman: New York, NY, USA, 2001.

34. Albert Gómez, M.J. La Investigación Educativa: Claves Teóricas; McGraw-Hill: Madrid, Spain, 2006.

35. Cohen, J. Statistical Power Analysis for the Behavioral Sciences, 2nd ed.; Lawrence Erlbaum: Hillsdale, NJ, USA, 1988; p. 567.

36. Abbas, J.; Aman, J.; Nurunnabi, M.; Bano, S. The impact of social media on learning behavior for sustainable education: Evidence of students from selected universities in Pakistan. Sustainability 2019, 11, 1683. [CrossRef]

37. Marfil-Carmona, R.; Chacón, P. Arts Education and Media Literacy in the Primary Education Teaching Degree of the University of Granada. Procedia Soc. Behav. Sci. 2017, 237, 1166-1172. [CrossRef]

38. Aguaded-Gómez, J.-I.; Sánchez Carrero, J. Niños y adolescentes tras el visor de la cámara: Experiencias de alfabetización audiovisual. Estud. Sobre Mensaje Periodístico 2008, 14, $293-308$.

39. Aguaded Gómez, J.I. Educación y medios de comunicación en el contexto iberoamericano. In Encuentros Iberoamericanos; Aguaded Gómez, J.I., Cabero Almenara, J., Eds.; Universidad Internacional de Andalucía, Sede Iberoamericana de la Rábida: Huelva, Spain, 1995; pp. 19-48.

40. Sturm, R.E.; Taylor, S.N.; Atwater, L.E.; Braddy, P.W. Leader self-awareness: An examination and implications of women's under-prediction. J. Organ. Behav. 2014, 35, 657-677. [CrossRef]

41. Herbst, T.H.H. Gender differences in self-perception accuracy: The confidence gap and women leaders' underrepresentation in academia. SA J. Ind. Psychol. 2020, 46, 1-8. [CrossRef]

42. Albert, M.A.; Dahling, J.J. Learning goal orientation and locus of control interact to predict academic self-concept and academic performance in college students. Personal. Individ. Differ. 2016, 97, 245-248. [CrossRef]

43. Jahan, S.; Palanivel, T.; Kovacevic, M.; Assa, J.; Bonini, A.; Calderón, C. Índices e Indicadores de Desarrollo Humano. Actualización Estadística de 2018. Programa de las Naciones Unidas para el Desarrollo; Programa de las Naciones Unidas para el Desarrollo (PNUD): New York, NY, USA, 2018.

44. Davis, C.; Novak, M.; Patel, A.; Davis, C.; Fitzwater, R.; Hale, N. The COVID-19 Catalyst: Analysis of a Tertiary Academic Institution's Rapid Assimilation of Telemedicine. Urol. Pract. 2020, 7, 247-251. [CrossRef]

45. Fontana Sierra, L. Pandemia y rearticulación de las relaciones sociales. Perifèria Rev. Investig. Form. Antropol. 2020, 25, 101-114.

46. Huertas, A.; Oliveira, A.; Girotto, M. Crisis communication management by the national tourist organizations of Spain and Italy in the face of Covid-19. Prof. Inf. 2020, 29, 1-18.

47. Sierra Caballero, F. Políticas de Comunicación y Educación: Crítica y Desarrollo de la Sociedad del Conocimiento; Gedisa: Barcelona, Spain, 2006; p. 318.

48. Montero Sánchez, D.; Moreno Domínguez, J.M. El Cambio Social a Través de las Imágenes: Guía para Entender y Utilizar el Vídeo Participativo; Catarata: Madrid, Spain, 2014; p. 143.

49. Schames Kreitchmann, R.; Abad, F.J.; Ponsoda, V.; Nieto, M.D.; Morillo, D. Controlling for Response Biases in Self-Report Scales: Forced-Choice vs. Psychometric Modeling of Likert Items. Front. Psychol. 2019, 10, 2309. [CrossRef] [PubMed]

Publisher's Note: MDPI stays neutral with regard to jurisdictional claims in published maps and institutional affiliations.

(C) 2020 by the authors. Licensee MDPI, Basel, Switzerland. This article is an open access article distributed under the terms and conditions of the Creative Commons Attribution (CC BY) license (http://creativecommons.org/licenses/by/4.0/). 